\title{
Correlation of Carbohydrate Content with the Changes in Amylase, Invertase and $\beta$-Galactosidase Activity of Ripe Mango Pulp During Storage under Different Temperatures
}

\author{
M. M. Rahman ${ }^{a *}$ M. M. Rahman ${ }^{\text {a }}$, N. Absar $^{\text {b }}$ and M. A. Ahsan \\ ${ }^{a}$ IFST, Bangladesh Council of Scientific and Industrial Research, Dhaka. ${ }^{b}$ Department of Biochemistry, \\ University of Rajshahi. ' Analytical Research Division, BCSIR Laboratories, Dhaka.
}

\begin{abstract}
Two good qualities of mango cultivars namely Fazli and Khirshapat, harvested at the full mature stage i.e. begining of ripening, have been stored at $-5^{\circ} \mathrm{C}, 4^{\circ} \mathrm{C}$ and $25 \pm 2{ }^{\circ} \mathrm{C}$ for 10 days and the changes in the content of amylase, invertase, $\beta$-galactosidase, starch, total sugar, reducing sugar and non-reducing sugar of the pulp were analyzed after 2-days regular interval of time. The activities of all the enzymes examined in the study were found to be higher in mango-pulp at $25^{\circ} \mathrm{C}$ as compared to those in $4{ }^{\circ} \mathrm{C}$ or $-5^{\circ} \mathrm{C}$. The activities of amylase and invertase decreased after 8-days of storage while that of $\beta$-galactosidase increased with the increasing days of storage mango pulp.

Total sugar and non-reducing sugar content of mango were increased gradually while starch content was decreased sharply with the increasing days of storage of mature mango. Changes in carbohydrate during storage of mango was found to be associated with the content of amylase, invertase and $\beta$-galactosidase. At $-5^{\circ} \mathrm{C}$ the enzymes as well as carbohydrate content of storage mango pulp changed slightly upto 4 days and thereafter the enzyme became fully dormant.
\end{abstract}

Key Words: Ripe mango, Carbohydrate, Amylase, Invertase, $\beta$-galactosidase, Temperatures

\section{Introduction}

Mango (Mangifera indica $\mathrm{L}$ ) is said to be the king of tropical fruits because of its high palatability, excellent taste, flavour and exemplary nutritive value.

Mango pulp contains amylase, invertase and high percentage of starch (Gangwar, et. al., 1973). Starch accumulation is the main activity of fruit for 90 days on the tree and accounts for $14 \%$ of the fresh weight of Alphonso mangoes at harvest but almost disappears within 8 days of storage (Caygill, et. al., 1976). Amylase and invertase in the mango pulp play an important role during the development of mango (Tandon, et. al., 1983).

The hydrolysis of starch during fruit ripening by hydrolytic enzymes has been reported for pear (Pech and Latehke, 1972). Changes in amylase activity in mango fruits during development and after being exposed to chilling temperatures, have been reported (Mattoo and Modi, 1969b).

$\beta$-galactosidase are widely distributed in various plant tissues including developing fruits (Bartley, 1974). The activities of $\beta$-galactosidase was increased remarkably during the ripening of apple (Bartley, 1974). Fruit softening during ripening is complex process that presumably involves structural changes in the walls of fruit cells. It is thought that these changes are brought about through the action of cell wall hydrolases degrading various wall polymers (Fischer and Bennett, 1991) although other mechanisms may be involved (Gross, 1990).

The present work constitutes a study on the changes in the content of carbohydrate and the activities of amylase, invertase and $\beta$-galactosidase during storing under different temperatures.

\section{Materials and Methods}

Two varieties of mango namely, Fazli and Khirshapat were selected for the present study. The mangoes were collected from Bangladesh Horticultural Research Station, Kazla, Rajshahi.

\section{Preparation of crude enzyme extract:}

Mango pulp $(10 \mathrm{~g})$ was grinded in a mortar with cold $0.1 \mathrm{M}$ phosphate buffer of respective $\mathrm{pH}$ (for amylase, $\mathrm{pH} 6.7$ and

\footnotetext{
*Corresponding author. E-mail:
} 
for invertase, $\mathrm{pH} 7.0$ ), 0.1M Na-citrate buffer $\mathrm{pH} 4.6$ for $\beta$ galactosidase and finally crushed into paste using a homogenizer. The temperature was maintained at $4^{\circ} \mathrm{C}$ by putting ice in the outer chamber of the homogenizer. The suspension was then filtered through few layers of cheese cloth in the cold room. The filtrate was collected and clarified further by centrifugation in a refrigerated centrifuge at $8,000 \mathrm{rpm}$ for 15 minutes at $4^{\circ} \mathrm{C}$.

\section{Assay of amylase, invertase and $\beta$-galactosidase activities}

Amylase activity was assayed by the method described in Laboratory Mannual in Biochemistry (Jayaraman, 1981). One percent starch solution was used as substrate (1 gm in $100 \mathrm{~mL}$ of $0.1 \mathrm{M}$ phosphate buffer, $\mathrm{pH}$ 6.7). The amylase activity was measured by estimating the release of amount of maltose calculated from the standard curve prepared with maltose. One unit of amylase activity was defined as the amount required for liberating $1 \mathrm{mg}$ of maltose in 15 minutes at $37^{\circ} \mathrm{C}$.

Invertase activity was assayed by the method as described in Method of Physiological Plant Pathology (Mahadevan and Sridhar, 1982), using sucrose as substrate. The invertase activity was measured by estimating the release of amount of glucose calculated from the standard curve prepared with glucose. One unit of invertase activity was defined as the amount required for liberating $1 \mathrm{mg}$ of glucose in 15 minutes at $37^{\circ} \mathrm{C}$.

$\beta$-galactosidase activity was determined by measuring the amount of galactose released from methyl- $\beta$-galactopyranoside. The reaction mixture consisted of $0.5 \mathrm{~mL}$ of $0.1 \mathrm{M}$ sodium citrate $(\mathrm{pH} 4.0), 0.5 \mathrm{~mL}$ of diluted enzyme and 0.5 $\mathrm{mL}$ of $13 \mathrm{mM}$ substrate. After incubation for 15 minutes at $37^{\circ} \mathrm{C}$, the reaction was terminated by the addition of $2 \mathrm{~mL}$ of $0.2 \mathrm{M}$ sodium carbonate. Amount of reducing sugar released was estimated by dinitrosalicylic acid (Miller, 1972). One unit of $\beta$-galactosidase activity was defined as the amount of enzyme that catalyzed the liberation of $1 \mathrm{mg}$ of galactose in 15 minutes at $37^{\circ} \mathrm{C}$ and the amount of galactose released was calculated from the standard curve prepared with galactose.

\section{Estimation of starch content}

The starch content of the mango pulp was estimated by the anthrone method as described in Laboratory Manual in Biochemistry (Jayaraman, 1981). The amount of starch present was calculated from standard curve of glucose.

\section{Determination of total sugar content}

Total sugars content of mango pulp was determined colorimetrically by the anthrone method (Jayaraman, 1981).
Extraction of sugar from mango pulp was done following the method of Loomis and Shull (1937) and the amount of total sugar present was calculated by constructing a standard curve with glucose.

\section{Determination of reducing sugar content}

Reducing sugar content of mango pulp was determined by Dinitrosalicylic acid method (Miller,1972). Extraction of sugar from mango pulp was done following the method of Loomis and Shull (1937) and the amount of reducing sugar present was calculated by constructing a standard curve with glucose.

\section{Determination of non-reducing sugar content}

Non- reducing sugar content was calculated from the following formula as reported by Ranganna (1979).

$\%$ Non- reducing sugar $=(\%$ Total sugar $-\%$ Reducing sugar) $\times 0.95$.

\section{Results and Discussion}

Two variety of mango harvested at the full mature stage i.e. begining of ripening have been stored for 10 days at $-5^{\circ} \mathrm{C}$, $4^{\circ} \mathrm{C}$ and $25 \pm 2^{\circ} \mathrm{C}$ in the study. The changes in starch, sugars, amylase, invertase and $\beta$-galactosidase contents in the pulp were analyzed. Fig. 1a, Fig. $1 \mathrm{~b}$ and Fig. 1c represent the changes in the activities of amylase, invertase and $\beta$-galactosidase of mango pulp after storing for 10 days respectively. At $-5^{\circ} \mathrm{C}$ the activities all enzymes were increasing slightly upto 4-days and after this period the activities of the enzymes remained almost constant while at $4^{\circ} \mathrm{C}$ the activities of enzymes were found to be increased gradually upto 10 days. On the other hand, at $25^{\circ} \mathrm{C} \beta$-galactosidase activity was increased gradually upto 10 days but the activities of amylase and invertase were increased gradually upto 8 days in the mango-pulp and the activities were found to be much higher at this temperature as compared to those in $4^{\circ} \mathrm{C}$ and $-5^{\circ} \mathrm{C}$. Strikingly the activity of the amylase decreased abruptly while that of invertase decreased moderately when the mango were stored more than 8 days at $25^{\circ} \mathrm{C}$. Further, the activities of $\beta$-galactosidase was increased more rapidly with the increasing days of storage.

The starch content of mango pulp was found to be disappeared significantly with the storage of ripening mango at or above $4^{\circ} \mathrm{C}$ (Fig. 2a). At $25^{\circ} \mathrm{C}$ and $4^{\circ} \mathrm{C}$ starch content in the pulp of both the varieties decreased drastically with increasing days of storage and the starch content disappeared completely after 8 -days of storage at $25^{\circ} \mathrm{C}$ while that decreased 


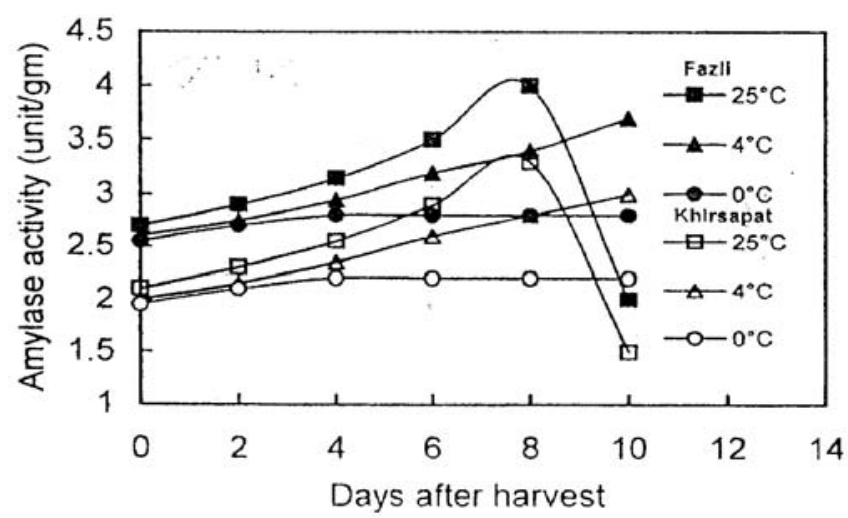

Fig. 1a: Changes in amylase activity during ripening of mango fruit storage under different temperatures

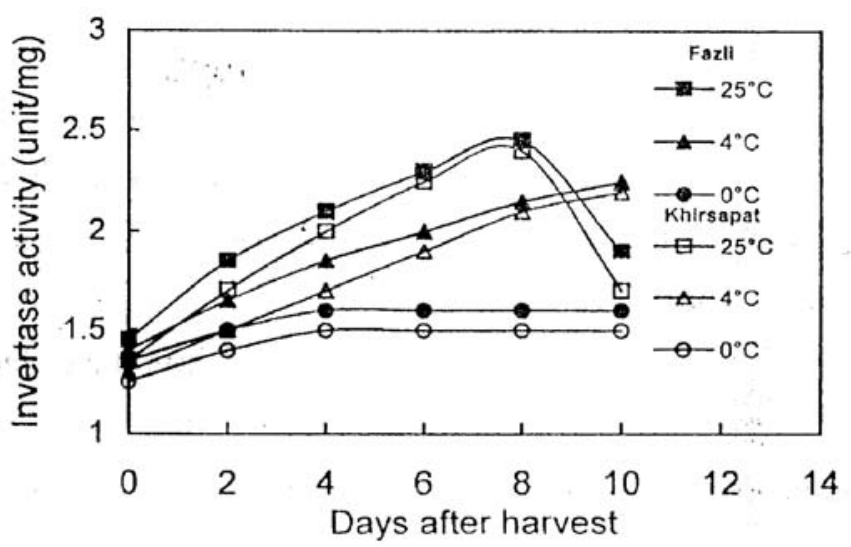

Fig. 1b: Changes in invertase activity during ripening of mango fruit storage under different temperatures

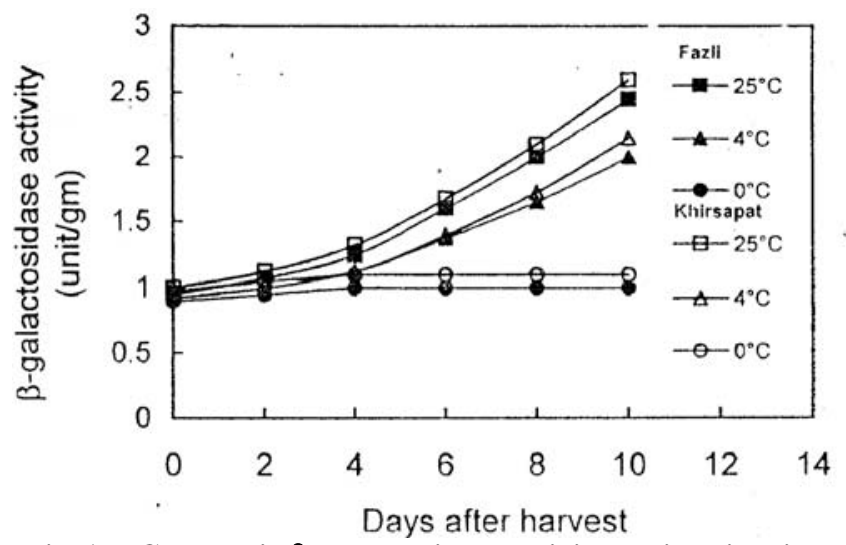

Fig. 1c: Changes in $\beta$-galactosidase activity during ripening of mango fruit storage under different temperatures

about $82 \%$ after 10 -days of storage at $4^{\circ} \mathrm{C}$. On the other hand , the starch content of mango-pulp decreased slightly upto 4days and thereafter remained unchanged even after storage of 10 days at $-5^{\circ} \mathrm{C}$ which shows good correlation with the activities of amylase as the enzyme became fully inactive after 4-days of storage. It was also reported that starch is the main carbohydrate present in mature green mango fruits (Matto, et. al. 1975) and during ripening of mango, the starch in mango-pulp is being hydrolyzed (Matto and Modi, 1969b). The present data indicated that the content of starch was disappeared completely after storage of ripening mango at $25^{\circ} \mathrm{C}$ for 8 -days and at the same time activities of amylase was decreased to $45 \%$ of 10 -days.

The total sugar (Fig.2b) as well as non-reducing sugar (Fig.3a) content of mango pulp were increased gradually when storage at $4{ }^{\circ} \mathrm{C}$ and $25^{\circ} \mathrm{C}$ and after 10 days of storage the total sugar and non-reducing sugar content of Fazli variety increased about $7.4 \%, 7.9 \%$ and $6.0 \%, 7.1 \%$ while that of Khirsapat increased about 7.2\%, 7.8\%,5.9\%, and 7.1\%

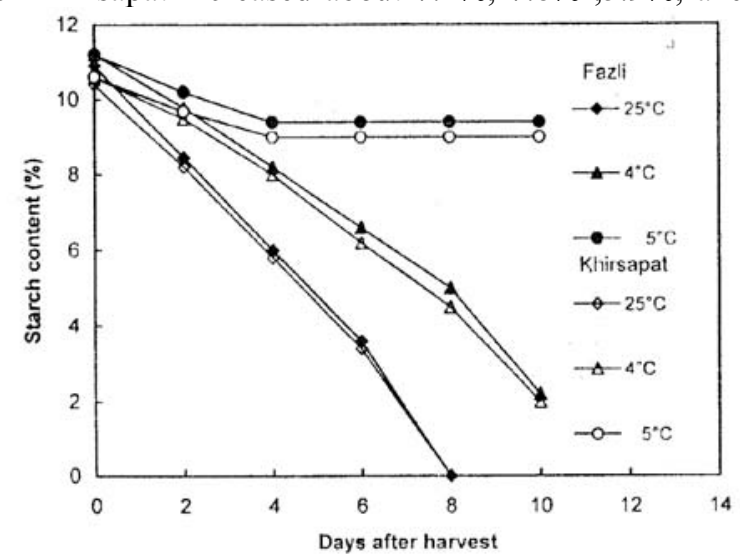

Fig. 2a: Changes in starch content during ripening of mango fruit storage under different temperatures

respectively. On the other hand, when the mango was kept at- $5^{\circ} \mathrm{C}$, the total sugar and non-reducing sugar content increased slightly upto 4 days and after this period no change was observed.

As shown (Fig. 3b), the reducing sugar content of both the varieties of mango pulp also increased gradually with

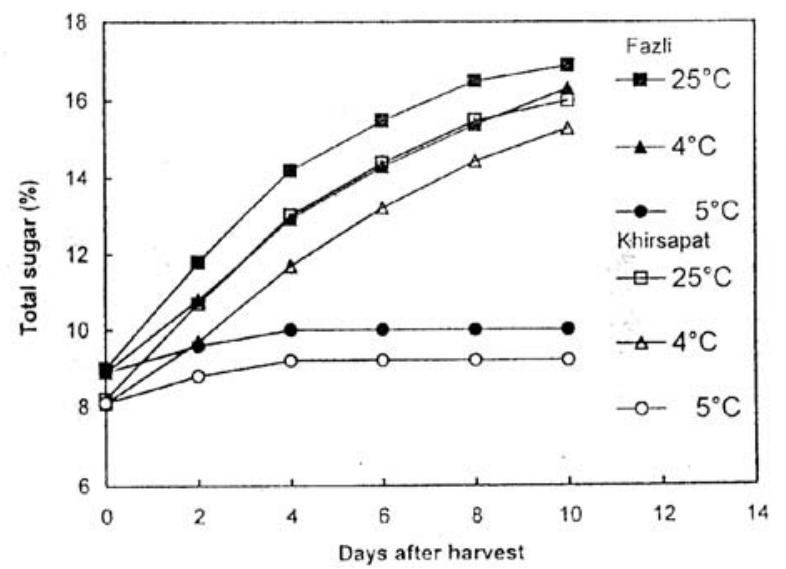

Fig. 2b: Changes in total sugar content during ripening of mango fruit storage under different temperatures 
increasing days of storage, upto 8 - days at $4^{\circ} \mathrm{C}$ and $25^{\circ} \mathrm{C}$. Significantly, the reducing sugar content decreased sharply after 8-days of storage at $25^{\circ} \mathrm{C}$ while that decreased moder

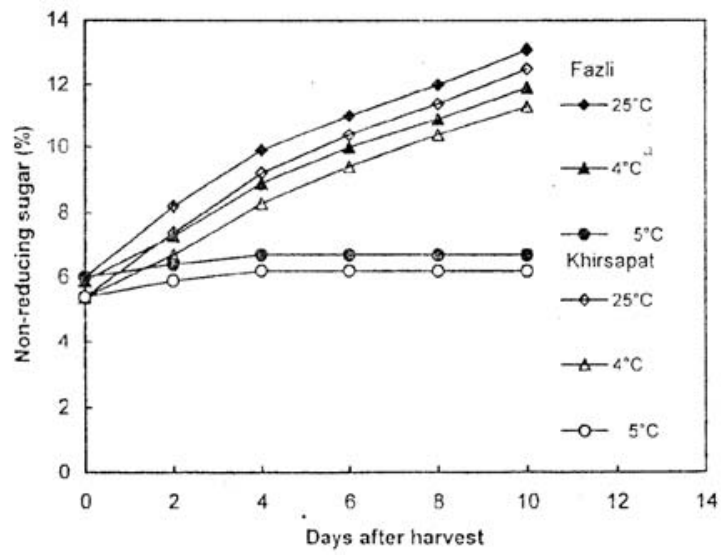

Fig. 3a : Changes in non-reducing sugar content during ripening of mango fruit storage under different temperatures

ately at $4^{\circ} \mathrm{C}$. When storage at $-5^{\circ} \mathrm{C}$, the amount of reducing sugar in the pulp increased slightly upto 4-days and thereafter no change was observed. The decrease in reducing sugar content after 8 -days of storage at $25^{\circ} \mathrm{C}$ and $4^{\circ} \mathrm{C}$ might be due to respiration and other energy consuming processes of the over ripening of mango (Matto, et.al., 1975).

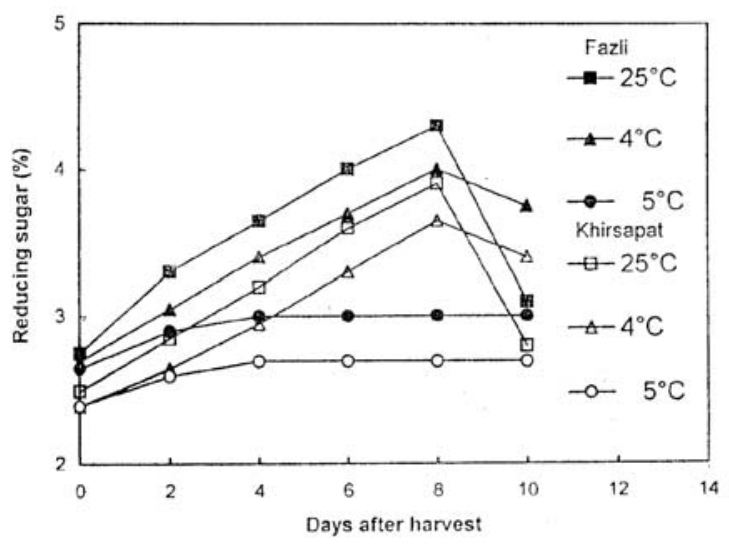

Fig. 3b : Changes in reducing sugar content during ripening of mango fruit storage under different temperatures

\section{Conclusion}

The changes in content of starch, total sugar, non-reducing sugar and reducing sugar show good correlation with the content of carbohydrate splitting enzymes such as amylase , invertase and $\beta$-galactosidase in mango-pulp with the increasing days of storage of mature mango after harvest. From the conducted experiments, it was observed that the Fazli variety was more effective than the Khirshapat variety.

\section{Acknowledgement}

The authors wish to thank the Chairman, Department of Biochemistry, Rajshahi University, Rajshahi, Bangladesh, for providing necessary facilities to carry out this work.

\section{References}

Bartley I. M. (1974). $\beta$-galactosidase activity in ripening apples. Phytochemistry, 13: 2107-2111.

Caygill J. C., R. D. Cooke D. J. Moore S. J. Read and H.C. Passam. (1976). The Mango (Mangifera indica L.) harvesting and subsequent handling and processing an annotated bibliography. Tropical products institute 56/62 Grays Inn Road London WC1 x 8 L U., P. 55.

Gangwar B. M. and R. S. Tripathi. (1973). A study on physicochemical changes during growth, maturity and ripening in mango. The Punjab Horticultural Journal, 13: 230-236.

Gross K. C. (1990). Recent developments on tomato fruit softening. Postharv. News Inf. 1: 109- 112.

Jayaraman J. (1981). Laboratoy manual in Biochemistry. Wiley Estern Ltd. New Delhi, India.

Loomis W. E. and C. A. Shull. (1937). Methods of plant physiology McGraw-Hill, New York.

Mattoo A. K. and V. V. Modi. (1969b). Biochemical aspects of ripening and chilling injury in mango fruit. Proc. Conf. Trop. Subtrop. Fruit (London). PP. 111-114.

Mahadevan A. and Sridhar R. (1982). Methods of physiological plant pathology (2nd ed). Sivakasi Publication. Madras, India.

Matto. A. K., Murata T., Er. B. Pantastico K., Chachin K. Ogata, and Phan C. T. (1975). Chemical changes during ripening and senescence. In: Er. B. Pantastico (Editor). Post harvest physicology, Handling and Utilization of Tropical and Subtropical fruits and vegetables. Avi, Westport. CT. pp. 103-127.

Miller G. L. (1972) . Use of dinitrosalicylic acid reagent for determination of reducing sugar. Anal. Chem., 31:426-428.

Pech J. C. and A. Latchke. (1972). Activities of enzymes involved in sugar metabolism in passe-cressane pears during cold storage . J. Sci. Food Agric., 23: 1499-1502.

Ranganna S. (1979). Manual of Analysis of Fruits and Vegetable products.

Tata McGraw-Hill Publishing Company Ltd., New Delhi.

Received: April, 18, 2010;

Accepted : April 25, 2011 